\title{
Church support networks of African Americans: The impact of gender and religious involvement
}

\author{
Ann W. Nguyen ${ }^{1} \odot \mid$ Robert Joseph Taylor $^{2}$ | Linda M. Chatters ${ }^{2} \odot$ | \\ Meredith O. Hope ${ }^{2}$
}

${ }^{1}$ Case Western Reserve University

${ }^{2}$ University of Michigan

Correspondence

Email: nguyena@case.edu

Funding information

National Institute on Aging, Grant/Award

Number: P30AG043073

\begin{abstract}
We examined the sociodemographic and religious involvement correlates of church support networks in a nationally representative sample of African Americans across the adult life span. Data from the National Survey of American Life was used for analysis. Ordinary least squares regression was conducted to identify correlates of frequency of contact, subjective closeness, provision and receipt of overall support, receipt of emotional support, and negative interactions with church members. We also investigated differences in church support networks separately for men and women. Religious involvement was positively associated with church support network indicators (i.e., frequency of contact). Church support network indicators also varied by age, gender, education, family income, marital status, and region. The findings indicate that for many African Americans, church members are an integral component of their support networks and underscore the importance of social integration in church networks for social support exchanges. Moreover, these church support network characteristics are patterned by sociodemographic characteristics.

\section{KEYWORDS}

black church, church support, informal support network, religion, religious involvement, social network, social support
\end{abstract}

Religious congregations have an enduring and prominent role in the development of African American communities (Lincoln \& Mamiya, 1990; Taylor, Chatters, \& Levin, 2004). Formally organized congregational initiatives and programs, as well as informal social support networks within religious communities, have provided a range of civic, educational, political, and cultural resources that enhance individual and community well-being. Further, given 
acknowledged difficulties in access, affordability, and appropriateness of traditional health and social welfare services (Taylor, Ellison, Chatters, Levin, \& Lincoln, 2000), African Americans often engage religiously sponsored initiatives, programs, and supports at rates that exceed their involvement in the professional service sector.

Despite the centrality of the Black Church in African American communities, the academic literature has given only sporadic attention to examining the potential strengths and resources that exist within religious communities. In contrast, community psychology, public health, and social work traditionally emphasize understanding the person within their social, cultural, and community environments. This body of research is notable for examining the types of assistance (e.g., material, emotional) provided by religious communities, as well as identifying the pathways and mechanisms through which church-based assistance promotes individual well-being (Chatters, 2000; Ellison \& Levin, 1998; Koenig, King, \& Carson, 2012; Maton, 1989, 2001; McMahon, Singh, Garner, \& Benhorin, 2004). Moreover, this study explores how sociodemographic characteristics and religious involvement factors are associated with receiving church assistance (Taylor, Chatters, \& Jackson, 2007; Taylor et al., 2004).

This study examines the sociodemographic and religious involvement correlates of church support networks among African Americans across the adult age range. Identifying sociodemographic correlates of church support networks provides more in depth information on the nature of social relationships and social support exchanges within the context of the church. Identifying sociodemographic correlates of church support networks also provides a more nuanced picture of how social resources are differentially distributed across subpopulations. In examining supportive exchanges, we focus on interactional features of church networks (e.g., frequency of contact), as well as emotional and qualitative characteristics (e.g., subjective closeness, negative interactions). The following literature review provides an overview of extant research on the characteristics and correlates of informal church support among African Americans and a discussion of negative interactions with church members.

\section{1 | CHURCH SUPPORT}

Given the historical importance of the church and the prominence of religion in the lives of African Americans, support from church members (i.e., church support) constitutes an important form of assistance for this population. Church support is distinct from other types of support, such as family and friendship assistance, because it is exchanged exclusively within a religious community among individuals who share similar values, beliefs, and norms (Taylor \& Chatters, 1988). Moreover, church support complements assistance that is provided by family members (Chatters, Nguyen, Taylor, \& Hope, 2018). Individuals who are estranged from their family or do not live near relatives often substitute support from church members for family support (Taylor et al., 2004) and identify church members as their surrogate "church" family.

Overall, African Americans are well-integrated into their church support networks (Krause, 2008; Taylor, Lincoln, \& Chatters, 2005). National survey data indicate that the vast majority of African Americans who are religiously involved (88\%) perceive their relationships with other congregants to be either very close or fairly close (Taylor et al., 2005) and over half of respondents reported frequent interactions with church members. With regard to support exchanges between church members, 60\% reported receiving frequent support from church member, including emotional support, tangible aid (e.g., money, services, in-kind), informational support, and counseling and advice (Taylor et al., 2004).

Church support is particularly important for community psychology because of its relationship to both mental and physical health. For instance, research has found that church support is associated with higher levels of selfrated health (Krause, 2002), higher rates of health care utilization (Krause, 2010) and lower rates of mortality (Krause, 2006). With regard to mental health outcomes, church support is associated with lower rates of depressive symptoms, serious psychological distress, and anxiety (Chatters et al., 2018). Church support is also associated with higher rates of psychological well-being and life satisfaction (Krause, Ellison, \& Wulff, 1998). In addition, support from church members is protective of suicidal behaviors (Chatters, Taylor, Lincoln, Nguyen, \& Joe, 2011). 
Church support seems to be a more important aspect of the support networks of African Americans than Whites. This is somewhat logical considering that African Americans have higher rates of weekly religious service attendance than Whites (Chatters, Taylor, Bullard, \& Jackson, 2009). Although the findings are mixed, the vast majority of research on church support networks also finds that African Americans are more involved in these networks than Whites (Krause, 2016; Krause \& Bastida, 2011; Taylor, Chatters, Woodward, \& Brown, 2013).

Research also finds that church support networks may be more important for African Americans' mental and physical health than for non-Hispanic Whites. For example, research on depressive symptoms (Assari \& Lankarani, 2018) and self-rated health (Krause, 2002) indicate that church support networks are more beneficial for the health of African Americans. Some have found that higher levels of church support and religious experiences more strongly predicted life satisfaction among African Americans than among Whites (Assari, 2013; Skarupski, Fitchett, Evans, \& Mendes de Leon, 2013). Assari's (2013) examination of race and ethnic differences in the association between church support and self-rated health found that church support predicted more positive self-rated health among African Americans.

However, among non-Hispanic Whites, church support was not predictive of self-rated health. Skarupski et al. (2013) suggested that this is due to a "faith advantage" for African Americans. Assari and Lankarani (2018) posited that congregational relationships may vary qualitative between African Americans and Whites, which could lead to a faith advantage for African Americans. Additionally, they suggested that racial and ethnic variations in the organization and programmatic emphasis of religious service and churches, patterns and contents of religious activities, and the structure and mission of church may contribute to these Black-White differences.

\section{1 | Negative interactions with church members}

Although positive social interactions with church members far outnumber problematic interactions, negative interactions are, nonetheless, an important aspect of church networks that have significant implications for mental and physical health. Empirical studies link negative interactions with church members to a range of mental (e.g., depressive symptoms, psychological distress) and physical health problems (e.g., heart disease; Chatters et al., 2018; Chatters, Taylor, Woodward, \& Nicklett, 2015; Ellison, Zhang, Krause, \& Marcum, 2009; Krause, 2005; Krause \& Hayward, 2012). Limited evidence on the correlates of negative church interactions indicates that women and individuals who have more frequent contact with church members experience more negative interactions (Nguyen, Taylor, \& Chatters, 2016). Conversely, income is negatively associated with negative church interactions (Nguyen et al., 2016); individuals with higher levels of income report fewer negative interactions than those with lower levels of income.

\subsection{Focus of the present study}

Given the prominence of religion and churches for African Americans, it is important to understand the degree to which individuals are involved in their church support networks. An in-depth understanding of church support networks requires attention to both the positive (receipt and provision of support) and problematic (negative interaction) aspects of these relationships. The present study examines how sociodemographic factors and religious involvement relates to multiple characteristics of church support networks, including frequency of contact with, subjective closeness to, social support exchanges between, and negative interactions with church members. This analysis is based on a national probability sample.

Research on frequency of contact, subjective closeness, and negative interactions with church members, while limited, identifies several sociodemographic and religious involvement correlates. Consistent with prior research on age, gender and regional differences in religious involvement (Taylor et al., 2004), we anticipate that older adults, women, and residents of the South will interact more frequently and endorse stronger perceptions of closeness to congregants. 
Similarly, Pentecostal affiliation and higher levels of service attendance will be associated with more frequent contact with and perceptions of closeness to church members. With regard to church support itself, we anticipate that women, those who were married, and those with less education and family income will receive and provide support to congregants more frequently than their respective counterparts. Further, high levels of religious engagement (contact with and closeness to members) and denominational identification as Pentecostal (as compared to Baptist) will be associated with providing and receiving church support more frequently.

Finally, based upon research on the correlates of negative church interactions (Nguyen et al., 2016), we expect that women, those with lower levels of income, those who have frequent contact with church members will experience more frequent negative interactions with church members.

Research on church support have identified gender differences in the receipt and provision of support. However, these gender differences are equivocal. Some studies have indicated that women receive more support from church members than men (Krause, 2004; Taylor et al., 2005). This is likely due to the fact that women tend to be more religious and attend religious services more frequently (Taylor, Chatters, \& Brown, 2014). Women also have more frequent contact with church members, which affords more opportunities for supportive exchanges to occur (Taylor et al., 2005). Thus, women not only receive more support from church members but also provide more support to church members than men (Nguyen et al., 2016).

In contrast, some studies have found that men receive support from church members more frequently than women (Taylor \& Chatters, 1988; Taylor, Chatters, Lincoln, \& Woodward, 2017). A possible explanation for this is that men who are involved in the church often hold positions of high status and visibility (e.g., deacon, board member), which may result in more support from church members (Taylor \& Chatters, 1988). Given these gender differences, correlates of church support may vary by gender as well. Thus, an additional aim of this study is to identify how correlates of church support may vary by gender. Because no study, to our knowledge, have examined how sociodemographic correlates of church support varies by gender, we do not make specific hypotheses for this gender stratified analysis.

\section{2 | METHOD}

\section{1 | Sample}

The analytic sample for this analysis was drawn from the National Survey of American Life: Coping with Stress in the $21^{\text {st }}$ Century (NSAL), which was collected by the Program for Research on Black Americans at the University of Michigan's Institute for Social Research. The African American sample is the core sample of the NSAL. Sixty-four primary sampling units composed the core sample, 56 of which overlapped substantially with existing Survey Research Center National Sample primary areas. The remaining eight primary areas were selected from the South to ensure representation of African Americans in the proportion in which they are nationally distributed.

\subsection{1 | Primary sampling units}

The African American sample is a nationally representative sample of households located in the 48 coterminous states with at least one Black adult aged 18 years or older who did not identify ancestral ties in the Caribbean. The data collection was conducted from February 2001 to June 2003. A total of 6,082 interviews were conducted with individuals aged 18 years or older, including 3,570 African Americans, 891 non-Hispanic Whites, and 1,621 Blacks of Caribbean descent.

Of the interviews, $14 \%$ were completed over the phone and $86 \%$ were administered face-to-face in respondents' homes. It is important to note that, consistent with research in this field, only those who indicated that they attend religious services at least a few times a year were asked the church support network questions. Those who attended religious services less than once a year were not asked the church support network questions. 
Thus, the analytic sample for this study comprised African Americans who attend religious services at least a few times a year $(N=2991)$.

Respondents were compensated for their time. The overall response rate was $72.3 \%$. Final response rates for the NSAL two-phase sample designs were computed using the American Association of Public Opinion Research (AAPOR) guidelines (for Response Rate 3 samples) (AAPOR, 2006; for a more detailed discussion of the NSAL sample, see Jackson, Neighbors, Nesse, Trierweiler, \& Torres, 2004). The NSAL data collection was approved by the University of Michigan Institutional Review Board.

\section{2 | Measures}

\subsection{1 | Church contact and relationships}

It is important to note that the term church members, to which the church contact, relationships, and support items refer, is defined as congregants and does not include pastors or church leaders. Frequency of contact with church members was measured by the question: "How often do you see, write or talk on the telephone with members of your church? Would you say nearly every day (6), at least once a week (5), a few times a month (4), at least once a month (3), a few times a year (2), or never (1)?" Subjective closeness to church members was assessed by the question: "How close are you to the people in your church? Would you say very close (4), fairly close (3), not too close (2), or not close at all (1)?" Negative interactions with church members was assessed using a three-item Likert type scale, with response categories ranging from 1 (never) to 4 (very often). Respondents were asked, "How often do the people in your church: 1) make too many demands on you, 2) criticize you and the things you do, and 3) try to take advantage of you?" $(\alpha=.73)$.

\subsection{2 | Church support}

Receipt of overall social support from church members was measured by the question, "How often do people in your church help you out? Would you say very often (4), fairly often (3), not too often (2), or never (1)?" Provision of social support to church members was measured by the question, "How often do you help out people in your church? Would you say very often (4), fairly often (3), not too often (2), or never (1)?" Receipt of emotional support from church members is assessed using a three-item Likert type scale, with response categories ranging from 1 (never) to 4 (very often). Respondents were asked "How often do the people in your church: 1) make you feel loved and cared for, 2) listen to you talk about your private problems and concerns, and 3) express interest and concern in your well-being?" $(\alpha=.71)$.

\subsection{3 | Religious involvement}

Church attendance was measured by the question, "How often do you usually attend religious services? Would you say nearly everyday, at least once a week, a few times a month, a few times a year, or less than once a year?" Denomination was measured by the question: "What is your current religion?" More than 35 different denominations were identified which were recoded into nine categories: Baptist, Methodist, Catholic, Pentecostal, Episcopalian, Seventh Day Adventist, Other Protestant (e.g., Lutheran, Presbyterian), Other Religion (e.g., Buddhist, Muslim), and Unaffiliated. Baptists were set as the reference group in the multivariate analysis.

\subsection{4 | Sociodemographic correlates}

The sociodemographic variables used in this analysis include gender, education, age, family income, marital status, and region. Gender was coded 0 for male and 1 for female, and education (number of formal years of schooling), age, and family income (in dollars) were assessed as continuous variables. Missing data for family income and 
education were imputed using an iterative regression-based multiple imputation approach incorporating information about age, sex, region, race, employment status, marital status, home ownership, and nativity of household residents.

Parental status was coded 1 for parent and 0 for not a parent. Incarceration history was coded 1 for ever been incarcerated in a prison, jail, detention center or reform school and 0 for never been incarcerated in a prison, jail, detention center or reform school. Marital status was represented by five categories: married or cohabiting, divorced, widowed, separated, and never married; married/co-habiting was designated as the reference category in multivariate analyses. Region was represented by four categories (South, North Central, Northeast, and West). South is the reference category in multivariate analyses.

\subsection{Analysis strategy}

Ordinary least squares (OLS) regression analyses were performed to identify the correlates of frequency of contact, subjective closeness, receipt of overall and emotional support, provision of support, and negative interactions with church members. The analyses were conducted for the total sample as well as separately for men and women. In instances in which there were ostensibly meaningful differences in the gender stratified analysis, interactions by gender were tested to determine if these differences were significant. Only interactions that were significant at the 0.05 level were included in the final regression analysis. Regression coefficients and standard errors are presented. The regression coefficients and standard errors take into account the complex multistage clustered design of the NSAL sample, unequal probabilities of selection, nonresponse, and poststratification.

A correlation matrix for all of the variables is included in Appendix. In all analyses, we checked for collinearity between the independent variables using the variance inflation factor diagnostic test. The largest variance inflation factor was less than 2.1, which is below both the threshold of 10 and the more stringent threshold of 4, which many researchers regard as an indicator of severe multicollinearity (O'Brien, 2007).

\section{3 | RESULTS}

Table 1 presents the characteristics of the sample and distribution of the study variables. Women made up $56 \%$ of the sample and respondents were, on average, 42 years of age. Overall, mean years of formal education was just over 12 years and the average family income was $\$ 36,832$. Eight of 10 respondents were parents (82\%) and $17 \%$ had been incarcerated at some point in their lives. Approximately, two of five respondents were either married or cohabiting; about one-third of the sample had never married. Slightly over half of the sample (56\%) resided in the South.

Close to half of all respondents (49\%) reported Baptist religious affiliation; the second most prevalent reported religious affiliation was other Protestant (18\%). With regard to religious involvement, the average church attendance level (mean $[M]=3.79$, standard deviation $[S D]=1.21$ ) was between a few times a year and a few times a month. The average level of contact with congregants was 3.79 (SD =1.74), and the average level of subjective closeness to congregants was $2.63(S D=1.03)$. Overall, respondents reported similar levels of provision $(M=2.64$, $S D=0.90)$ and receipt $(M=2.41, S D=0.97)$ of overall support. On average, respondents reported receiving more emotional support from church members $(M=8.86, S D=2.10)$ than negative interactions with church members $(M=4.49, S D=1.65)$.

Findings from the multivariate analysis for frequency of contact with church members (Table 2) indicated that older respondents, women, and those who attended church more frequently had more contact with church members. Relative to Baptists, respondents who were Pentecostal had more frequent contact with church members. In contrast, compared with Baptists, religiously unaffiliated respondents had less contact with church members. Respondents in the West reported less contact with church members than their Southern counterparts. There was a significant 
TABLE 1 Demographic characteristics of the sample and distribution of study variables

\begin{tabular}{|c|c|c|c|c|c|c|}
\hline & $\%$ & $N$ & $M$ & $S D$ & Min & Max \\
\hline Age & & 3570 & 42.33 & 14.50 & 18 & 93 \\
\hline \multicolumn{7}{|l|}{ Gender } \\
\hline Male & 44.03 & 1271 & & & & \\
\hline Female & 55.97 & 2299 & & & & \\
\hline Education & & 3570 & 12.43 & 2.23 & 0 & 17 \\
\hline Family income & & 3570 & 36832.7 & 33068.1 & 0 & 520000 \\
\hline \multicolumn{7}{|l|}{ Parental status } \\
\hline Parent & 82.17 & 2992 & & & & \\
\hline Not a parent & 17.83 & 561 & & & & \\
\hline Incarceration history & & 3519 & 0.17 & 0.33 & 0 & 1 \\
\hline \multicolumn{7}{|l|}{ Marital status } \\
\hline Married/cohabiting & 41.65 & 1220 & & & & \\
\hline Separated & 7.16 & 286 & & & & \\
\hline Divorced & 11.75 & 524 & & & & \\
\hline Widowed & 7.90 & 353 & & & & \\
\hline Never married & 31.55 & 1170 & & & & \\
\hline \multicolumn{7}{|l|}{ Region } \\
\hline Northeast & 15.69 & 411 & & & & \\
\hline North Central & 18.81 & 595 & & & & \\
\hline South & 56.24 & 2330 & & & & \\
\hline West & 9.25 & 234 & & & & \\
\hline \multicolumn{7}{|l|}{ Denomination } \\
\hline Baptist & 49.08 & 1865 & & & & \\
\hline Methodist & 5.88 & 216 & & & & \\
\hline Pentecostal & 8.62 & 304 & & & & \\
\hline Catholic & 5.96 & 202 & & & & \\
\hline Other Protestant & 17.70 & 566 & & & & \\
\hline Other religion & 2.25 & 71 & & & & \\
\hline Unaffiliated & 10.51 & 344 & & & & \\
\hline Church attendance & & 3570 & 3.79 & 1.21 & 1 & 6 \\
\hline Frequency of contact & & 3569 & 3.20 & 1.74 & 1 & 6 \\
\hline Subjective closeness & & 3561 & 2.63 & 1.03 & 1 & 4 \\
\hline Provision of support & & 2803 & 2.64 & 0.90 & 1 & 4 \\
\hline Receipt of overall support & & 2347 & 2.41 & 0.97 & 1 & 4 \\
\hline Receipt of emotional support & & 2981 & 8.86 & 2.10 & 2 & 12 \\
\hline Negative interactions & & 2980 & 4.49 & 1.65 & 2 & 12 \\
\hline
\end{tabular}

Note. $\mathrm{M}=$ mean; $\mathrm{SD}=$ standard deviation.

Percents and $\mathrm{N}$ are presented for categorical variables and means and standard deviations are presented for continuous variables. Percentages are weighted and frequencies are unweighted.

interaction between gender and incarceration history. This interaction revealed that women who were formerly incarcerated had less contact with church members than women who had never been incarcerated; this was not the case for men. Possible interactions between gender and age, gender and marital status, and gender and region were not significant.

For subjective closeness (Table 2), women reported lower levels of subjective closeness to congregants than men and higher education was associated with lower assessments of subjective closeness. Individuals residing in the West had lower levels of subjective closeness than those residing in the South. Respondents belonging to other 
TAB LE 2 Multivariate analysis of the correlates of frequency of contact with and subjective closeness to church members among African Americans

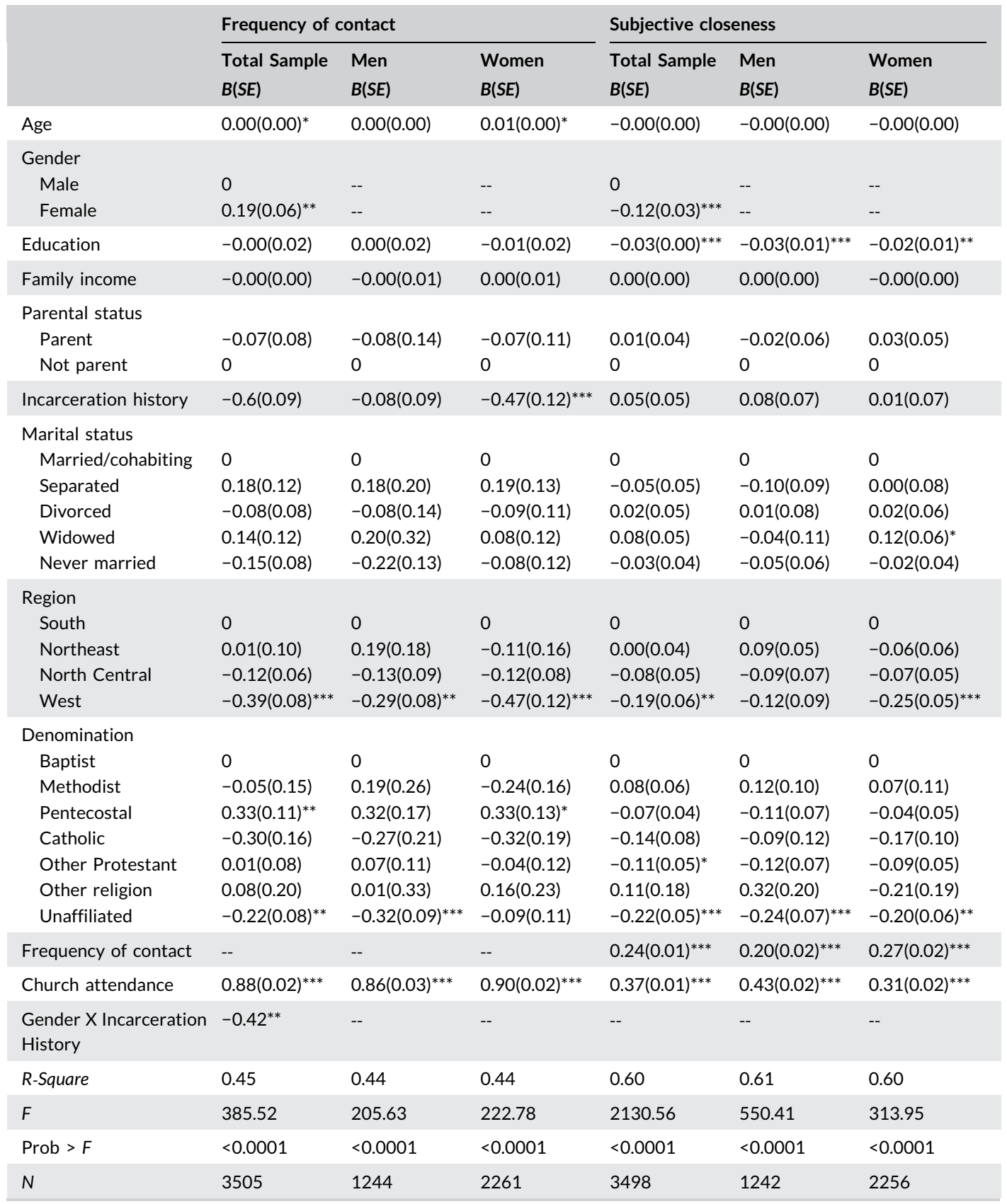

Note. $\mathrm{B}=$ regression coefficient; $\mathrm{SE}=$ standard error.

Significance test of the individual parameter estimates were based on a complex design-corrected $t$ test.

${ }^{*} p<0.05$.

${ }^{* *} p<0.01$.

${ }^{* * *} p<0.001$. 
Protestant denominations and religiously unaffiliated respondents reported being less subjectively close to other congregants as compared to Baptist respondents. Both frequency of contact and church attendance were positively associated with subjective closeness. That is, frequent service attendance and frequent interaction with church members were both associated with higher levels of subjective closeness to church members. Possible interactions between gender and marital status as well as gender and region were not significant.

Table 3 presents findings for the regression analysis of the provision and receipt of overall support. With regard to the provision of support, women were less likely than men to provide support to church members, whereas those with higher levels of family income provided more support to congregants than those with lower incomes. Respondents who were divorced provided church support to congregants more frequently than those who were married or cohabiting. Similarly, Methodists and respondents of other religious affiliations provided support to congregants more frequently than Baptists. Frequency of contact, subjective closeness, and church attendance were positively associated with the provision of support to church members. A possible interaction between gender and marital status was tested but not significant.

With regard to receiving overall support (Table 3), older people received less support than their younger counterparts. Respondents who were previously incarcerated received overall support less frequently. Residents of the Northeast and North Central regions reported receiving overall social support from their fellow congregants more frequently as compared to residents in the South. Higher levels of religious involvement (i.e., church attendance, contact with church members, and subjective closeness) were associated with receiving overall support from congregants more frequently. There was a significant interaction between gender and parental status among men, such that those who were parents received support less frequently than those who did not have children. However, among women, there was no association between parental status and receipt of overall support. Possible interactions between gender and age as well as gender and region were not significant.

Table 4 presents the multivariate analysis of the receipt of emotional support and negative interactions. Findings for emotional support indicate that older adults received less emotional support from congregants, whereas residents of the Northeast and West received more emotional support compared with residents in the South. Denominational differences indicated that Pentecostal and Catholic affiliations were associated with more frequent emotional support from church members compared with Baptist affiliation. In addition, higher levels of contact, subjective closeness, and church attendance were associated with more frequent emotional support. Interactions were tested between gender and education, and gender and region and were not significant.

Finally, findings for negative interactions with church members showed that women had fewer negative interactions than men (Table 4), whereas divorced respondents had more negative interactions. Respondents residing in the Northeast and those with higher levels of contact and subjective closeness to church members also reported more frequent negative interactions with church members. Church attendance, however, was unrelated to negative interactions with congregants. Interactions were tested between gender and marital status, and gender and region and were not significant.

\section{4 | DISCUSSION}

Overall, our findings indicate that for many African Americans church members are an integral component of their social support networks. They report being emotionally close to their church support networks. Further, they indicate that they receive emotional support and both provide and receive overall assistance from church members on a relatively frequent basis. The findings of this study add to the emerging body of research on the importance of church support networks among African Americans.

One of the most consistent findings in this analysis is that integration and involvement in church networks were associated with receiving and providing more support. This is evident for service attendance, frequency of contact with church members, and degree of subjective closeness to church members. Previous studies involving different 
TABLE 3 Multivariate analysis of the correlates of the frequency of provision of social support to and receipt of overall social support from church members among African Americans

\begin{tabular}{|c|c|c|c|c|c|c|}
\hline & \multicolumn{3}{|c|}{ Provision of social support } & \multicolumn{3}{|c|}{ Receipt of overall support } \\
\hline & $\begin{array}{l}\text { Total sample } \\
B(S E)\end{array}$ & $\begin{array}{l}\text { Men } \\
B(S E)\end{array}$ & $\begin{array}{l}\text { Women } \\
B(S E)\end{array}$ & $\begin{array}{l}\text { Total sample } \\
B(S E)\end{array}$ & $\begin{array}{l}\text { Men } \\
B(S E)\end{array}$ & $\begin{array}{l}\text { Women } \\
B(S E)\end{array}$ \\
\hline Age & $0.00(0.00)$ & $0.00(0.00)$ & $0.00(0.00)$ & $\begin{array}{l}-0.01 \\
(0.00)^{* * *}\end{array}$ & $-0.00(0.00)$ & $-0.01(0.00)^{* *}$ \\
\hline \multicolumn{7}{|l|}{ Gender } \\
\hline Male & 0 & -- & -- & 0 & -- & -- \\
\hline Female & $-0.11(0.04)^{* *}$ & -- & -- & $-0.01(0.05)$ & -- & -- \\
\hline Education & $-0.00(0.01)$ & $-0.01(0.01)$ & $0.00(0.01)$ & $-0.01(0.01)$ & $-0.00(0.02)$ & $-0.01(0.01)$ \\
\hline Family income & $0.01(0.00)^{* * *}$ & $0.01(0.00)^{* *}$ & $0.01(0.00)^{* *}$ & $0.00(0.00)$ & $0.00(0.01)$ & $0.00(0.00)$ \\
\hline \multicolumn{7}{|l|}{ Parental status } \\
\hline Parent & $0.04(0.06)$ & $-0.08(0.09)$ & $0.14(0.07)$ & $0.24(0.08)^{* *}$ & $-0.25(0.09)^{* *}$ & $0.01(0.09)$ \\
\hline Not parent & 0 & 0 & 0 & 0 & 0 & 0 \\
\hline Incarceration history & $0.01(0.05)$ & $0.03(0.07)$ & $-0.05(0.07)$ & $-0.12(0.06)^{*}$ & $-0.10(0.09)$ & $-0.18(0.10)$ \\
\hline \multicolumn{7}{|l|}{ Marital status } \\
\hline Married/cohabiting & 0 & 0 & 0 & 0 & 0 & 0 \\
\hline Separated & $0.11(0.08)$ & $-0.04(0.12)$ & $0.21(0.09)^{*}$ & $-0.04(0.10)$ & $-0.09(0.19)$ & $-0.01(0.12)$ \\
\hline Divorced & $0.15(0.06)^{*}$ & $0.11(0.11)$ & $0.20(0.06)^{* *}$ & $-0.09(0.08)$ & $0.01(0.12)$ & $-0.15(0.09)$ \\
\hline Widowed & $0.00(0.09)$ & $-0.00(0.15)$ & $0.04(0.10)$ & $0.09(0.10)$ & $0.15(0.16)$ & $0.09(0.10)$ \\
\hline Never married & $0.07(0.05)$ & $0.03(0.07)$ & $0.11(0.06)$ & $0.08(0.06)$ & $0.19(0.09)$ & $0.03(0.08)$ \\
\hline \multicolumn{7}{|l|}{ Region } \\
\hline South & 0 & 0 & 0 & 0 & 0 & 0 \\
\hline Northeast & $0.13(0.08)$ & $0.12(0.10)$ & $0.15(0.11)$ & $0.28(0.09)^{* *}$ & $0.12(0.14)$ & $0.39(0.10)^{* * *}$ \\
\hline North Central & $0.05(0.05)$ & $0.02(0.10)$ & $0.07(0.04)$ & $0.13(0.05)^{*}$ & $0.05(0.08)$ & $0.18(0.08)^{*}$ \\
\hline West & $-0.04(0.06)$ & $0.09(0.12)$ & $-0.15(0.10)$ & $-0.05(0.06)$ & $0.06(0.11)$ & $-0.12(0.07)$ \\
\hline \multicolumn{7}{|l|}{ Denomination } \\
\hline Baptist & 0 & 0 & 0 & 0 & 0 & 0 \\
\hline Methodist & $0.16(0.08)^{*}$ & $0.19(0.15)$ & $0.13(0.12)$ & $-0.14(0.08)$ & $-0.28(0.15)$ & $-0.05(0.06)$ \\
\hline Pentecostal & $0.11(0.06)$ & $0.05(0.12)$ & $0.12(0.08)$ & $-0.02(0.08)$ & $0.05(0.15)$ & $-0.06(0.11)$ \\
\hline Catholic & $0.12(0.09)$ & $0.21(0.11)$ & $0.03(0.09)$ & $0.10(0.08)$ & $0.26(0.13)^{*}$ & $-0.00(0.09)$ \\
\hline Other Protestant & $0.03(0.05)$ & $0.11(0.08)$ & $-0.04(0.06)$ & $0.03(0.07)$ & $0.05(0.11)$ & $-0.01(0.08)$ \\
\hline Other religion & $0.43(0.15)^{* *}$ & $0.40(0.19)^{*}$ & $0.44(0.15)^{* *}$ & $0.06(0.18)$ & $0.02(0.21)$ & $0.15(0.25)$ \\
\hline Unaffiliated & $0.08(0.10)$ & $-0.05(0.14)$ & $0.21(0.11)$ & $0.06(0.09)$ & $-0.14(0.15)$ & $0.28(0.09)^{* *}$ \\
\hline Frequency of contact & $0.11(0.01)^{* * *}$ & $0.11(0.02)^{* * *}$ & $0.10(0.02)^{* * *}$ & $0.09(0.01)^{* * *}$ & $0.12(0.02)^{* * *}$ & $0.07(0.02)^{* * *}$ \\
\hline Subjective closeness & $0.43(0.03)^{* * *}$ & $0.45(0.04)^{* * *}$ & $0.42(0.03)^{* * *}$ & $0.45(0.02)^{* * *}$ & $0.43(0.04)^{* * *}$ & $0.46(0.03)^{* * *}$ \\
\hline Church attendance & $0.14(0.02)^{* * *}$ & $0.10(0.04)^{* *}$ & $0.17(0.03)^{* * *}$ & $0.13(0.03)^{* * *}$ & $0.13(0.05)^{*}$ & $0.14(0.04)^{* *}$ \\
\hline Gender X Parental Status & -- & -- & -- & $-0.24(0.12)^{*}$ & -- & -- \\
\hline R-Square & 0.37 & 0.38 & 0.37 & 0.31 & 0.35 & 0.30 \\
\hline$F$ & 145.19 & 67.89 & 224.93 & 138.83 & 101.14 & 114.83 \\
\hline Prob $>F$ & $<0.0001$ & $<0.0001$ & $<0.0001$ & $<0.0001$ & $<0.0001$ & $<0.0001$ \\
\hline$N$ & 2745 & 916 & 1829 & 2297 & 758 & 1539 \\
\hline
\end{tabular}

Note. $\mathrm{B}=$ regression coefficient; $\mathrm{SE}=$ standard error.

Significance test of the individual parameter estimates were based on a complex design-corrected $t$ test.

${ }^{*} p<0.05$.

${ }^{* *} p<0.01$.

${ }^{* * *} p<0.001$. 
TABLE 4 Multivariate analysis of the correlates of the frequency of receipt of emotional support and negative interaction with church members among African Americans

\begin{tabular}{|c|c|c|c|c|c|c|}
\hline & \multicolumn{3}{|c|}{ Receipt of emotional support } & \multicolumn{3}{|c|}{ Negative interactions } \\
\hline & Total & Men & Women & Total & Men & $\begin{array}{l}\text { Women } \\
B(S F)\end{array}$ \\
\hline & & & & & & \\
\hline Age & $-0.01(0.00)^{* *}$ & $-0.02(0.01)^{* *}$ & $-0.01(0.01)^{*}$ & $-0.00(0.00)$ & $-0.00(0.00)$ & $-0.00(0.00)$ \\
\hline \multicolumn{7}{|l|}{ Gender } \\
\hline Male & 0 & -- & -- & 0 & -- & -- \\
\hline Female & $-0.01(0.10)$ & -- & -- & $-0.23(0.09)^{*}$ & -- & -- \\
\hline Education & $-0.04(0.02)$ & $-0.08(0.03)^{*}$ & $-0.01(0.02)$ & $0.02(0.02)$ & $0.02(0.03)$ & $0.02(0.03)$ \\
\hline Family income & $0.01(0.01)$ & $0.01(0.01)$ & $0.00(0.01)$ & $0.01(0.01)$ & $0.00(0.01)$ & $0.01(0.01)$ \\
\hline \multicolumn{7}{|l|}{ Parental status } \\
\hline Parent & $-0.01(0.13)$ & $0.12(0.22)$ & $-0.14(0.17)$ & $0.09(0.11)$ & $0.16(0.20)$ & $0.06(0.15)$ \\
\hline Not parent & 0 & 0 & 0 & 0 & 0 & 0 \\
\hline Incarceration history & $-0.01(0.12)$ & $-0.06(0.16)$ & $0.02(0.19)$ & $0.25(0.13)$ & $0.31(0.16)$ & $0.13(0.22)$ \\
\hline \multicolumn{7}{|l|}{ Marital status } \\
\hline Married/cohabiting & 0 & 0 & 0 & 0 & 0 & 0 \\
\hline Separated & $0.25(0.16)$ & $0.18(0.27)$ & $0.34(0.22)$ & $0.25(0.17)$ & $0.20(0.27)$ & $0.25(0.17)$ \\
\hline Divorced & $0.06(0.12)$ & $0.06(0.19)$ & $0.12(0.15)$ & $0.19(0.09)^{*}$ & $-0.05(0.22)$ & $0.31(0.14)^{*}$ \\
\hline Widowed & $0.12(0.15)$ & $0.11(0.29)$ & $0.16(0.23)$ & $-0.04(0.15)$ & $-0.05(0.24)$ & $-0.06(0.18)$ \\
\hline Never married & $0.08(0.09)$ & $0.06(0.21)$ & $0.14(0.11)$ & $0.08(0.12)$ & $0.29(0.23)$ & $-0.02(0.16)$ \\
\hline \multicolumn{7}{|l|}{ Region } \\
\hline South & 0 & 0 & 0 & 0 & 0 & 0 \\
\hline Northeast & $0.42(0.08)^{* * *}$ & $0.34(0.23)$ & $0.50(0.15)^{* *}$ & $0.26(0.11)^{*}$ & $0.58(0.18)^{* *}$ & $0.05(0.11)$ \\
\hline North Central & $0.15(0.15)$ & $0.26(0.20)$ & $0.07(0.20)$ & $0.20(0.15)$ & $0.18(0.33)$ & $0.21(0.08)^{*}$ \\
\hline West & $0.33(0.16)^{*}$ & $0.50(0.19)^{*}$ & $0.25(0.33)$ & $0.13(0.19)$ & $0.25(0.24)$ & $0.02(0.21)$ \\
\hline \multicolumn{7}{|l|}{ Denomination } \\
\hline Baptist & 0 & 0 & 0 & 0 & 0 & 0 \\
\hline Methodist & $-0.24(0.13)$ & $-0.24(0.20)$ & $-0.27(0.20)$ & $-0.05(0.15)$ & $-0.25(0.21)$ & $0.09(0.23)$ \\
\hline Pentecostal & $0.24(0.11)^{*}$ & $-0.08(0.17)$ & $0.38(0.13)^{* *}$ & $0.01(0.12)$ & $0.37(0.29)$ & $-0.08(0.17)$ \\
\hline Catholic & $0.35(0.14)^{*}$ & $0.28(0.29)$ & $0.35(0.18)$ & $0.22(0.24)$ & $0.19(0.43)$ & $0.29(0.17)$ \\
\hline Other Protestant & $0.08(0.12)$ & $0.03(0.18)$ & $0.13(0.13)$ & $-0.09(0.13)$ & $0.01(0.18)$ & $-0.20(0.15)$ \\
\hline Other religion & $0.53(0.33)$ & $0.74(0.34)^{*}$ & $0.23(0.49)$ & $-0.12(0.35)$ & $-0.18(0.51)$ & $-0.13(0.33)$ \\
\hline Unaffiliated & $-0.29(0.21)$ & $-0.69(0.32)^{*}$ & $0.15(0.26)$ & $0.12(0.16)$ & $0.14(0.23)$ & $0.12(0.26)$ \\
\hline Frequency of contact & $0.17(0.03)^{* * *}$ & $0.21(0.04)^{* * *}$ & $0.13(0.04)^{* *}$ & $0.14(0.02)^{* * *}$ & $0.20(0.04)^{* * *}$ & $0.09(0.03)^{*}$ \\
\hline Subjective closeness & $1.19(0.07)^{* * *}$ & $1.10(0.08)^{* * *}$ & $1.27(0.08)^{* * *}$ & $0.16(0.03)^{* * *}$ & $0.18(0.07)^{*}$ & $0.14(0.06)^{*}$ \\
\hline Church attendance & $0.21(0.06)^{* *}$ & $0.14(0.07)^{*}$ & $0.25(0.08)^{* *}$ & $-0.04(0.06)$ & $0.01(0.09)$ & $-0.10(0.06)$ \\
\hline R-Square & 0.35 & 0.36 & 0.35 & 0.04 & 0.08 & 0.03 \\
\hline$F$ & 163.64 & 43.01 & 79.66 & 9.91 & 5.19 & 5.65 \\
\hline Prob $>F$ & $<0.0001$ & $<0.0001$ & $<0.0001$ & $<0.0001$ & $<0.0001$ & $<0.0001$ \\
\hline$N$ & 2923 & 975 & 1948 & 2922 & 974 & 1948 \\
\hline
\end{tabular}

Note. $\mathrm{B}=$ regression coefficient; $\mathrm{SE}=$ standard error.

Significance test of the individual parameter estimates were based on a complex design-corrected $t$-test.

${ }^{*} p<0.05$.

${ }^{* *} p<0.01$.

${ }^{* * *} p<0.001$. 
samples (elderly and adult African Americans and adult Black Caribbeans) similarly confirm the importance of church attendance, frequency of contact with church members, and subjective closeness to church members for congregational support exchanges (Hayward \& Krause, 2013; Nguyen et al., 2016; Taylor et al., 2005). Krause (2004) and Hayward and Krause (2013) found that older African Americans who reported more frequent service attendance also reported receiving more frequent support from church members. Among Black Caribbeans, frequent service attendance is predictive of receiving and providing church support on a more frequent basis (Nguyen et al., 2016). People who are more involved in their church networks have more opportunities to develop and strengthen social ties with fellow congregants. This leads to greater social embeddedness within the church network and higher levels of support exchanges with congregants, which the current findings demonstrate.

Nevertheless, higher levels of involvement in the church network affords additional opportunities for conflicts and disagreements with congregants. Consequently, respondents who reported more frequent contact with church members also reported more frequent negative interactions with these same individuals. We also found that respondents who reported higher levels of subjective closeness to church members also reported more frequent negative interactions with church members.

These findings are similar to prior results suggesting that it is not uncommon for close relationships to be simultaneously positive and negative (Birditt et al., 2018; Mouzon, Taylor, Nguyen, \& Chatters, 2016). Negative interactions are likely to be less prevalent in relationships that are not subjectively close because individuals in these relationships are able to use avoidance as a means to manage negative interactions. However, with close relationships, avoidance proves to be a difficult strategy for maintaining support networks. Thus, negative interactions are virtually unavoidable in subjectively close relationships.

Our findings for demographic differences in church support networks both confirmed and diverged from prior work. Research on family and friendship networks typically finds that gender is one of the strongest and most consistent correlates of network integration. Similar to previous research on kin and nonkin networks (Turner \& Turner, 2013), our analysis found that women had more frequent contact with church members than men, possibly reflecting gender and cultural norms that emphasize women's roles as social facilitators ("tend and mend"). Women also reported fewer negative interactions with church members compared with men. In contrast, however, women also reported lower levels of subjective closeness to church members and provided support less frequently. In essence, African American men were more subjectively close and provided support to church members more frequently compred with women, but they also had less contact with church members and more negative interactions.

The present finding that men provide more support may owe to the fact that they are more likely to hold positions of higher status and visibility within the church (e.g., deacon or member of the board of trustees) that place them in roles of responsibility and oversight for church resources and support exchanges within the congregation (Taylor \& Chatters, 1988; Taylor et al., 2017). Additionally, it is important to note that gender differences were significant only in the presence of controls for service attendance and contact with church members, both of which African American women reported higher levels. As such, discrepant gender differences might be attributable to the absence of controls for church attendance and contact with members in many previous studies.

Nonetheless, these findings collectively demonstrate that African American men who are heavily involved with their churches are both subjectively closer to congregants and provide support at relatively high levels. In previous research on older African Americans (Taylor et al., 2009), men reported significantly more hours per week at their place of worship compared with women. In addition to specific congregational roles and activities (men's club, choir), men may be involved as volunteers for maintaining the church building and grounds and general stewardship (e.g., cleaning, cutting grass, shoveling snow, opening and closing buildings; Taylor et al., 2009; Taylor et al., 2017). For this group of men, churches and their members are major components of their informal support networks.

The data also revealed a couple of gender interactions, indicating that certain demographic characteristics predicted church relationships differently for men and women. First, the significant interaction between gender and 
parental status demonstrated that compared to their nonparent male counterparts, African American men who were parents were less likely to receive overall support from congregants. Among African American women, there was no association between parental status and receipt of overall support. This pattern of support may owe to the fact that men may be more likely to seek support from family rather than from church members and other nonkin individuals.

Indeed, Chatters, Taylor, Lincoln, and Schroepfer (2002) investigation of patterns of social support from family and church members among African Americans indicated that compared with women, men are more likely to receive support from family members than church members (Chatters et al., 2002). As a result, men who were parents may have relied more on their children and other family members for support than on church members, which would explain why these respondents received less emotional support from congregants than men who were not parents. In contrast, men who did not have children may have relied more heavily on church members for emotional support; this is consistent with the notion that church members act as surrogate family to individuals who lack family ties (Chung, Bemak, \& Wong, 2000).

A second significant interaction indicated that women who were previously incarcerated had less contact with church members than women who had no history of incarceration. On the other hand, incarceration history had no bearing on how frequently men interacted with church members. This is likely due to the stigmatization of incarceration (Austin, 2004). This stigmatization is particularly magnified among women because incarceration rates are substantially lower among women than men; women comprise only $7 \%$ of the prison population (Federal Bureau of Prisons, 2018). Because incarceration is far less common among women, the stigma that accompanies it is much greater, which results in women who were previously incarcerated being socially isolated and, to a certain extent, ostracized from their church networks (Bengtson, 2001).

Study findings indicated that older people as opposed to younger people had more frequent contact with church members, yet they were less likely to receive overall support and emotional support. Higher rates of contact with church members among African Americans is consistent with their higher service attendance and religious participation rates (Chatters, Nguyen, \& Taylor, 2014). That is, African Americans frequently attend church services and tend to be more involved in church activities, which translates to more opportunities for social interactions with church members.

Negative associations between age and support are consistent with research on African American family support networks in which older adults are less likely than their younger counterparts to receive assistance from family members (Taylor, Mouzon, Nguyen, \& Chatters, 2016). However, findings for age differences in relation to church support are mixed. Some studies indicate that younger African Americans receive more church-based social support than their older counterparts (Krause, 2004; Taylor \& Chatters, 1988), whereas other work reports that no significant age differences (Taylor et al., 2005). The current findings on age may be indicative of the shrinking of the size of church support networks among older adults. Because of mortality of friends, older adults have smaller friendship networks. This is especially true of older adults of advanced age (75 years and older). Although church support networks may be a bit more intergenerational than strictly peer based friendship networks, they may still be much smaller than networks of younger adults. The smaller church networks of older adults may be the reason that older African Americans receive support from church members less frequently.

Regional differences found in this analysis show an interesting pattern of findings. First, African Americans residing in the South had more frequent contact with church members compared with those residing in the West region. Southerners also had higher levels of subjective closeness to church members compared with those residing in the West. These findings are consistent with well-established research showing that African American Southerners have higher rates of service attendance and participation in other activities at their places of worship (choir, women's and men's club; Taylor et al., 2014; Taylor et al., 2004). These higher rates of participation are likely attributable to the historical centrality of religion and religious communities in the South (Chung et al., 2000), in contrast to the lower rates of religious participation in the West.

Given this, we would also expect that African American Southerners would be more likely <zaq;2> to provide and receive social support. African Americans in the Northeast, however, were more likely<zaq;2> to receive both 
overall and emotional support. Similarly, respondents in the North Central region were more likely than Southerners to receive overall support, and those who resided in the West were more likely <zaq;2> to receive emotional support. These findings are counterintuitive and inconsistent with prior findings and expectations. However, it is important to remember that this analysis controlled for frequency of both church attendance and contact with church members and subjective closeness.

Further, both measures of integration with church networks (i.e., church attendance and contact with church members) are associated with region, with Southerners reporting higher levels of integration <zaq;2>. As such, controlling these variables reduces the impact of the higher level of church integration reported by Southerners. Ancillary analysis (not shown) without controls for service attendance and contact with church members revealed two significant region differences. Namely, Southerners were more likely than those residing in the West to both receive overall support and give support.

As with other correlates, the issue of denominational differences in church support networks is seriously understudied. The present analysis found that compared with Baptists, (a) Pentecostals had more frequent contact with church members, (b) Methodists provided more support, and (c) Pentecostals and Catholics received more emotional support. This pattern of findings is consistent with previous research indicating higher levels of service attendance and participation in church-based activities from members of this denomination (Taylor et al., 2014).

\section{1 | Limitations}

This study has several limitations that should be acknowledged. First, the study's cross-sectional design does not permit an assessment of the ongoing and reciprocal nature of church support exchanges and relationships. More broadly, our interpretations of sociodemographic differences are suggestive and await confirmation with prospective data. Second, the analyses were conducted on data collected in 2001-2003, which may limit the generalizability of the findings.

Finally, despite the acknowledged advantages of survey formats for exploring a broad range of issues, in-depth qualitative data could provide additional insight into how support operates in particular situations (e.g., health problems) and the specific form that it takes. Despite these limitations this study provided a comprehensive examination of church support networks among African Americans. The study had the benefit of a large national sample, which allowed the investigation of a full range of sociodemographic and church network (e.g., frequency on interaction, subjective closeness) independent variables.

\subsection{Implications for future research}

A major contribution of the present study is the resulting practice implications. Prior empirical work has indicated that higher levels of social integration within the church network and social support from church members can protect against a range of mental health problems, such as depressive symptoms, suicidality, and psychological distress (Chatters et al., 2018; Chatters et al., 2011; Nguyen et al., 2017). The current findings identified correlates of social integration and support within church networks. Given the association between social support and mental health problems, these correlates can be used to identify vulnerable clients who are at risk for developing or deteriorating mental health problems and to assess clients' social resources. Being able to identify vulnerable clients will permit practitioners to target interventions that would bolster the social support needs of clients. These interventions can be tailored to address issues of social disengagement, problematic relationships, and inadequate supports.

\section{3 | Directions for future research}

Several directions for future research include dedicated research on church support based on samples of the entire adult age range that explore potential age group differences in the correlates and nature of church support. This 
could involve examining age-specific types of support for young, middle-aged, and older people and exploring age differences in patterns of giving versus receiving assistance. Future research could also examine antecedent events (e.g., sudden financial hardship, death of a loved one) associated with providing and receiving church support. Taken together, this study provided a unique opportunity to systematically investigate and clarify sociodemographic and religious involvement correlates of church support and negative interactions among African American adults.

\section{4 | Conclusion}

The present study provided important information concerning church support networks of African Americans. Findings for the positive relationships between church involvement factors and church support underscore the importance of integration in church networks for receiving assistance. Study findings also contribute to a growing body of research on the nature of negative interactions with social groups (e.g., family, friends). In the case of church networks, higher levels of involvement comes at some cost with regard to perceptions that others criticize you, take advantage of you, and make too many demands. Further, the data indicated that some sociodemographic characteristics (i.e., parental status and incarceration history) function differently for men and women in relation to congregational relationships. These findings extend the literature on gender differences in social relationships.

\section{ORCID}

Ann W. Nguyen (D) http://orcid.org/0000-0002-2592-0773

Linda M. Chatters (D) http://orcid.org/0000-0002-4678-2541

\section{REFERENCES}

Adams, B., Aranda, M. P., Kemp, B., \& Takagi, K. (2002). Ethnic and gender differences in distress among Anglo American, African American, Japanese American, and Mexican American spousal caregivers of persons with dementia. Journal of Clinical Geropsychology, 8(4), 279-301.

Agresti, A. (2013). Categorical data analysis (3rd ed.). Hoboken: John Wiley \& Sons.

American Association for Public Opinion Research (2006). Standard definitions: Final dispositions of case codes and outcome rates for surveys (4th ed.). Lenexa, KS: Author.

Assari, S. (2013). Race and ethnicity, religion involvement, church-based social support and subjective health in United States: A case of moderated mediation. International Journal of Preventive Medicine, 4(2), 208-217.

Assari, S. (2018). Health disparities due to diminished return among black Americans: Public policy solutions. Social Issues and Policy Review, 12(1), 112-145.

Assari, S., \& Lankarani, M. M. (2018). Secular and religious social support better protect Blacks than Whites against depressive symptoms. Behavioral Sciences, 8(5), 46.

Austin, R. (2004). The shame of it all: Stigma and the political disenfranchisement of formerly convicted and incarcerated persons. Columbia Human Rights Law Review, 36, 173-192.

Bengtson, V. L. (2001). Beyond the nuclear family: The increasing importance of multigenerational bonds. Journal of Marriage and Family, 63(1), 1-16.

Birditt, K. S., Sherman, C. W., Polenick, C. A., Becker, L., Webster, N. J., Ajrouch, K. J., \& Antonucci, T. C. (2018). So close and yet so irritating: Negative relations and implications for well-being by age and closeness. The Journals of Gerontology: Series B, gby038-gby038. https://doi.org/10.1093/geronb/gby038

Chatters, L. M. (2000). Religion and health: Public health research and practice. Annual Review of Public Health, 21(1), 335-367.

Chatters, L. M., Nguyen, A. W., Taylor, R. J., \& Hope, M. O. (2018). Church and family support networks and depressive symptoms among African Americans: Findings from the National Survey of American Life. Journal of Community Psychology, 46(4), 403-417. https://doi.org/10.1002/jcop.21947

Chatters, L. M., Nguyen, A. W. \& Taylor, R. J. (2014). Religion and spirituality among older African Americans, Asians, and Hispanics. In K. E. Whitfield, \& T. A. Baker (Eds.), Handbook of minority aging (pp. 47-64). New York: Springer Publishing Company.

Chatters, L. M., Taylor, R. J., Bullard, K. M., \& Jackson, J. S. (2009). Race and ethnic differences in religious involvement: African Americans, Caribbean blacks and non-Hispanic whites. Ethnic and Racial Studies, 32(7), 1143-1163. 
Chatters, L. M., Taylor, R. J., Lincoln, K. D., Nguyen, A., \& Joe, S. (2011). Church-based social support and suicidality among African Americans and Black Caribbeans. Archives of Suicide Research, 15(4), 337-353. https://doi.org/10.1080/ 13811118.2011.615703

Chatters, L. M., Taylor, R. J., Lincoln, K. D., \& Schroepfer, T. (2002). Patterns of informal support from family and church members among African Americans. Journal of Black Studies, 33(1), 66-85. https://doi.org/10.1177/002193470203300104

Chatters, L. M., Taylor, R. J., Woodward, A. T., \& Nicklett, E. J. (2015). Social support from church and family members and depressive symptoms among older African Americans. American Journal of Geriatric Psychiatry, 23(6), 559-567. https:// doi.org/10.1016/j.jagp.2014.04.008

Chung, R. C. -Y., Bemak, F., \& Wong, S. (2000). Vietnamese refugees' levels of distress, social support, and acculturation: Implications for mental health counseling. Journal of Mental Health Counseling, 22(2), 150-161.

Ellison, C. G., \& Levin, J. S. (1998). The religion-health connection: Evidence, theory, and future directions. Health Education \& Behavior, 25(6), 700-720.

Ellison, C. G., Zhang, W., Krause, N., \& Marcum, J. P. (2009). Does negative interaction in the church increase psychological distress? Longitudinal findings from the Presbyterian Panel Survey. Sociology of Religion, 70(4), 409-431. https://doi. org/10.1093/socrel/srp062

Federal Bureau of Prisons (2018). Inmate gender. Retrieved from https://www.bop.gov/about/statistics/statistics_inmate_ gender.jsp

Hayward, R. D., \& Krause, N. (2013). Changes in church-based social support relationships during older adulthood. The Journals of Gerontology Series B: Psychological Sciences and Social Sciences, 68(1), 85-96.

Jackson, J. S., Neighbors, H. W., Nesse, R. M., Trierweiler, S. J., \& Torres, M. (2004). Methodological innovations in the National Survey of American Life. International Journal of Methods in Psychiatric Research, 13(4), 289-298.

Koenig, H. G., King, D., \& Carson, V. B. (2012). Handbook of religion and health (2nd ed.). New York: Oxford University Press.

Krause, N. (2002). Church-based social support and health in old age: Exploring variations by race. The Journals of Gerontology Series B: Psychological Sciences and Social Sciences, 57(6), S332-S347.

Krause, N. (2004). Common facets of religion, unique facets of religion, and life satisfaction among older African Americans. The Journals of Gerontology Series B: Psychological Sciences and Social Sciences, 59(2), S109-S117.

Krause, N. (2005). Negative interaction and heart disease in late life: Exploring variations by socioeconomic status. Journal of Aging and Health, 17(1), 28-55.

Krause, N. (2006). Church-based social support and mortality. The Journals of Gerontology Series B: Psychological Sciences and Social Sciences, 61(3), S140-S146.

Krause, N. (2008). Aging in the church: How social relationships affect health. West Conshohocken, PA: Templeton Press.

Krause, N. (2010). Close companions at church, health, and health care use in late life. Journal of Aging Health, 22(4), 434-453. https://doi.org/10.1177/0898264309359537

Krause, N. (2016). Assessing supportive social exchanges inside and outside religious institutions: Exploring variations among Whites, Hispanics, and Blacks. Social Indicators Research, 128(1), 131-146.

Krause, N., \& Bastida, E. (2011). Social relationships in the church during late life: Assessing differences between African Americans, whites, and Mexican Americans. Review of Religious Research, 53(1), 41-63.

Krause, N., Ellison, C. G., \& Wulff, K. M. (1998). Church-based emotional support, negative interaction, and psychological well-being: Findings from a national sample of Presbyterians. Journal for the Scientific Study of Religion, 37(4), 725-741. https://doi.org/10.2307/1388153

Krause, N., \& Hayward, R. D. (2012). Negative interaction with fellow church members and depressive symptoms among older Mexican Americans. Archive for the Psychology of Religion, 34(2), 149-171.

Lincoln, C. E., \& Mamiya, L. H. (1990). The Black church in the African American experience. Durham, NC: Duke University Press.

Maton, K. I. (1989). Community settings as buffers of life stress? Highly supportive churches, mutual help groups, and senior centers. American Journal of Community Psychology, 17(2), 203-232.

Maton, K. I. (2001). Spirituality, religion, and community psychology: Historical perspective, positive potential, and challenges. Journal of Community Psychology, 29(5), 605-613.

McMahon, S., Singh, J., Garner, L., \& Benhorin, S. (2004). Taking advantage of opportunities: Community involvement, wellbeing, and urban youth. Journal of Adolescent Health, 34(4), 262-265.

Mouzon, D. M., Taylor, R. J., Nguyen, A. W., \& Chatters, L. M. (2016). Serious psychological distress among African Americans: Findings from the National Survey of American Life. Journal of Community Psychology, 44(6), 765-780. https://doi.org/10.1002/jcop.21800

Nguyen, A. W., Chatters, L. M., Taylor, R. J., Aranda, M. P., Lincoln, K. D., \& Thomas, C. S. (2017). Discrimination, serious psychological distress, and church-based emotional support among African American men across the life span. The Journals of Gerontology: Series B, 73(2), 198-207. https://doi.org/10.1093/geronb/gbx083

Nguyen, A. W., Taylor, R. J., \& Chatters, L. M. (2016). Church-based social support among Caribbean Blacks in the United States. Review of Religious Research, 58, 385-406. https://doi.org/10.1007/s13644-016-0253-6 
O'Brien, R. M. (2007). A caution regarding rules of thumb for variance inflation factors. Quality \& quantity, 41(5), 673-690.

Skarupski, K. A., Fitchett, G., Evans, D. A., \& Mendes de Leon, C. F. (2013). Race differences in the association of spiritual experiences and life satisfaction in older age. Aging \& Mental Health, 17(7), 888-895. https://doi.org/10.1080/ 13607863.2013.793285

Taylor, R. J., \& Chatters, L. M. (1988). Church members as a source of informal social support. Review of Religious Research, 30(2), 193-203. https://doi.org/10.2307/3511355

Taylor, R. J., Chatters, L. M., \& Brown, R. K. (2014). African American religious participation. Review of Religious Research, 56(4), 513-538. https://doi.org/10.1007/s13644-013-0144-z

Taylor, R. J., Chatters, L. M., \& Jackson, J. S. (2007). Religious and spiritual involvement among older African Americans, Caribbean blacks, and non-Hispanic whites: Findings from the National Survey of American life. The Journals of Gerontology Series B: Psychological Sciences and Social Sciences, 62(4), S238-S250.

Taylor, R. J., Chatters, L. M., \& Levin, J. (2004). Religion in the lives of African Americans: Social, psychological, and health perspectives. Thousand Oaks, CA: SAGE.

Taylor, R. J., Chatters, L. M., Lincoln, K. D., \& Woodward, A. T. (2017). Church-based exchanges of informal social support among African Americans. Race and Social Problems, 9(1), 53-62. https://doi.org/10.1007/s12552-017-9195-z

Taylor, R. J., Chatters, L. M., Bullard, K. M., Wallace, J. M., \& Jackson, J. S. (2009). Organizational religious behavior among older African Americans: Findings from the National Survey of American Life. Research on Aging, 31(4), 440-462. https://doi.org/10.1177/0164027509333453

Taylor, R. J., Chatters, L. M., Woodward, A. T., \& Brown, E. (2013). Racial and ethnic differences in extended family, friendship, fictive kin, and congregational informal support networks. Family Relations, 62(4), 609-624. https://doi.org/ 10.1111/fare.12030

Taylor, R. J., Ellison, C. G., Chatters, L. M., Levin, J. S., \& Lincoln, K. D. (2000). Mental health services in faith communities: The role of clergy in black churches. Social Work, 45(1), 73-87.

Taylor, R. J., Lincoln, K. D., \& Chatters, L. M. (2005). Supportive relationships with church members among African Americans. Family Relations, 54(4), 501-511.

Taylor, R. J., Mouzon, D. M., Nguyen, A. W., \& Chatters, L. M. (2016). Reciprocal family, friendship and church support networks of African Americans: Findings from the National Survey of American Life. Race and Social Problems, 8(4), 326-339. https://doi.org/10.1007/s12552-016-9186-5

Turner, J. B., \& Turner, R. J. (2013). Social relations, social integration, and social support. In C. S. Aneshensel, J. C. Phelan \& A. Bierman (Eds.), Handbook of the sociology of mental health (pp. 341-356). New York: Springer.

How to cite this article: Nguyen AW, Taylor RJ, Chatters LM, Hope MO. Church support networks of African Americans: The impact of gender and religious involvement. J Community Psychol. 2019;47: 1043-1063. https://doi.org/10.1002/jcop.22171 


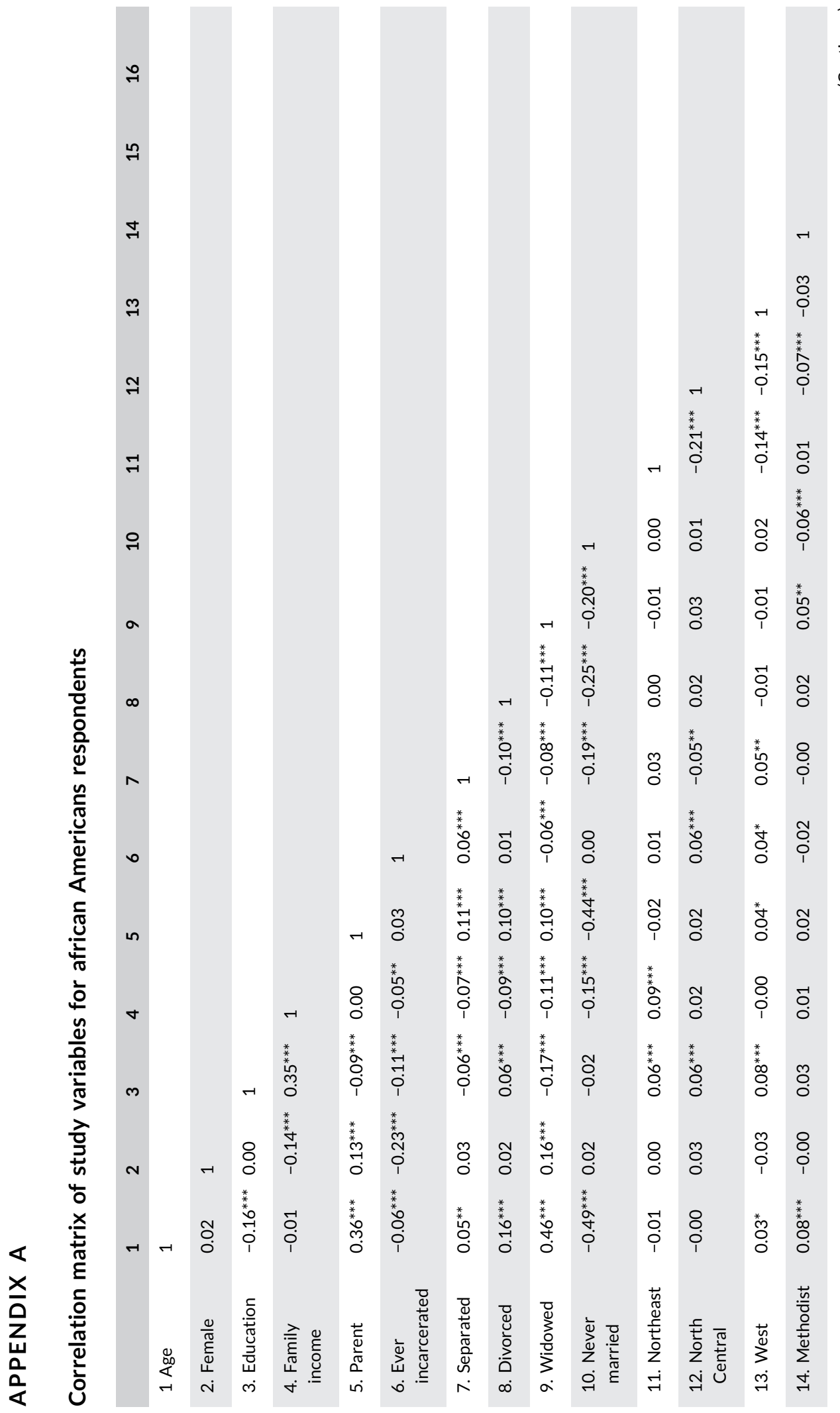




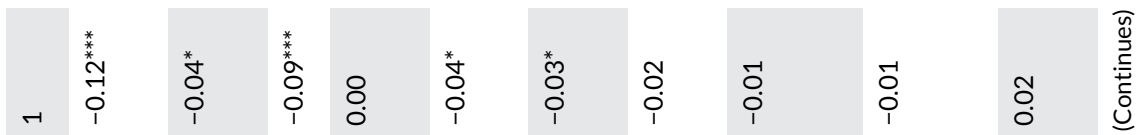

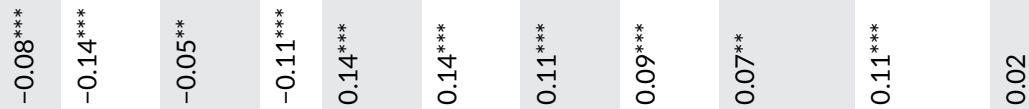

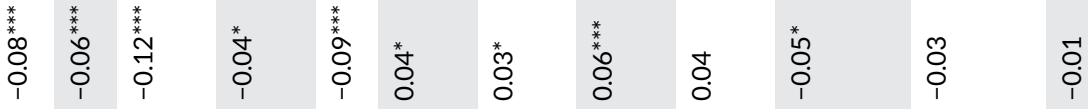

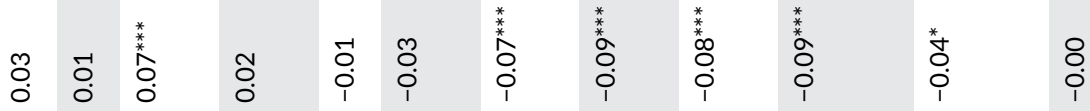

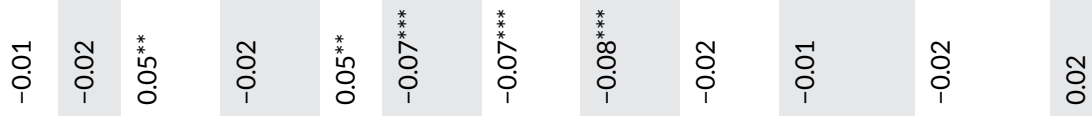

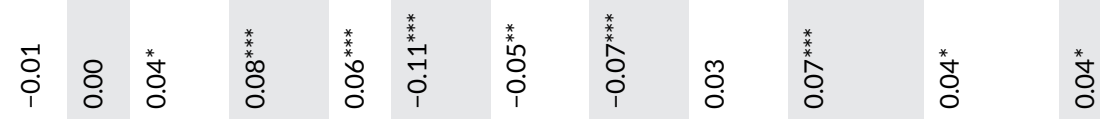

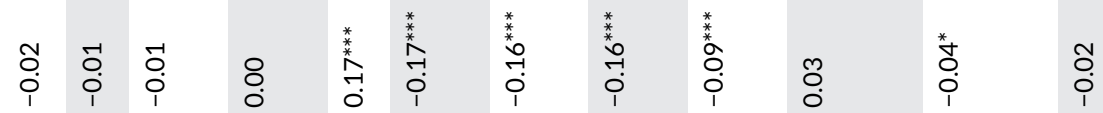

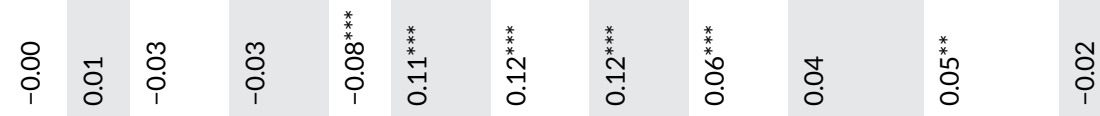

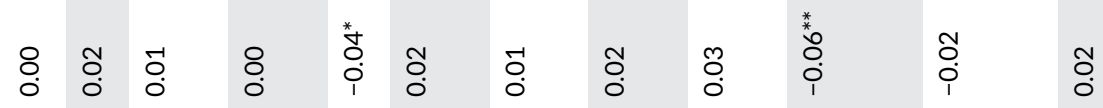

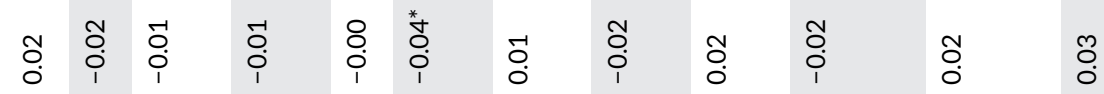

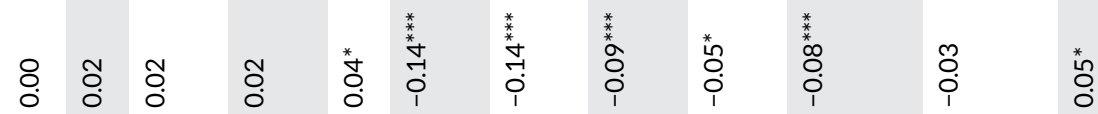

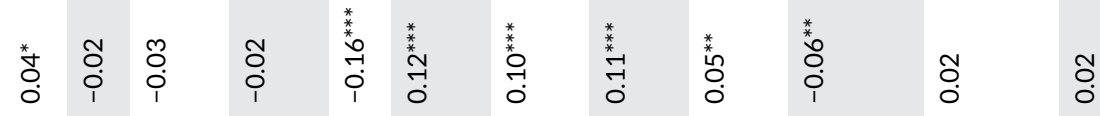

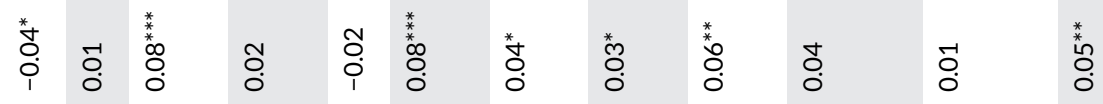

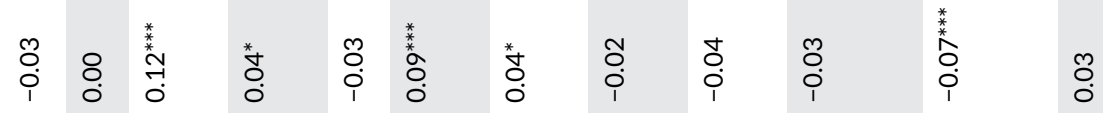

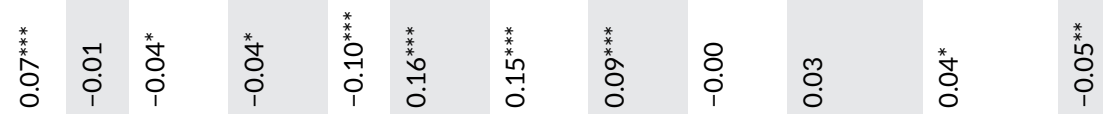

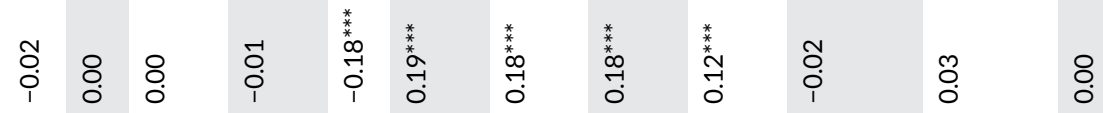

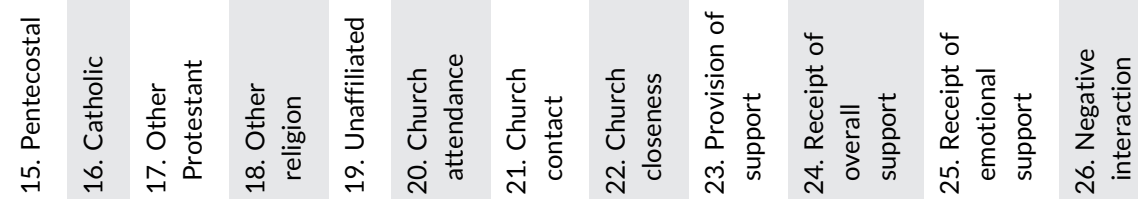




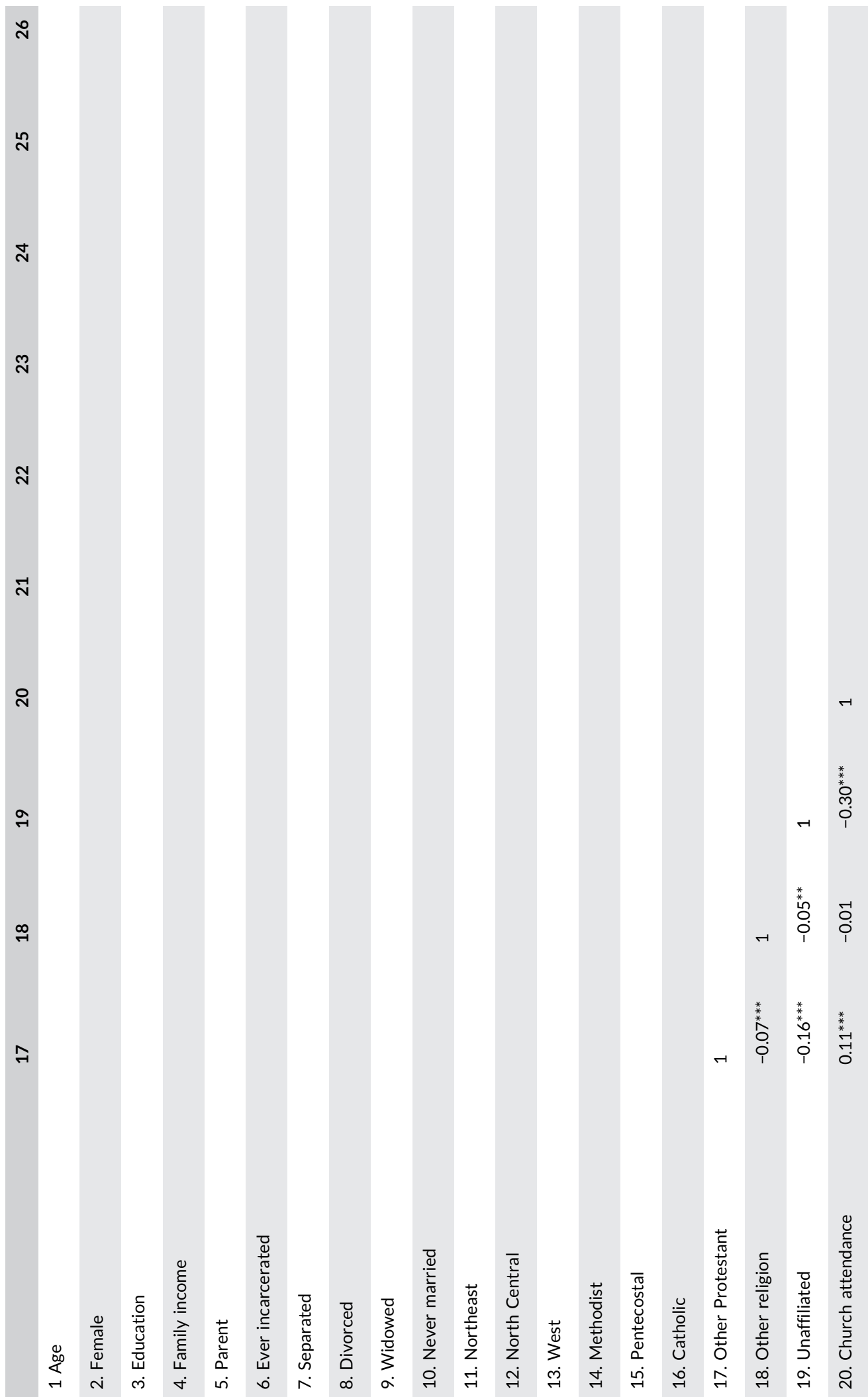




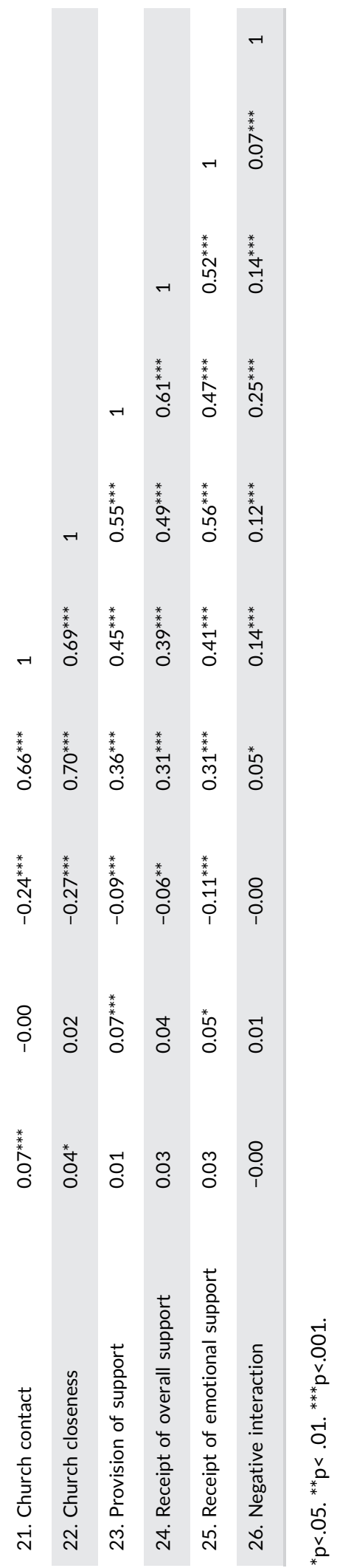

